\section{Legal niceties end an era}

FRINCH scientists were on the streets of Paris last week demonstrating against what placards described at the "strangling" of public research by a government that has cut ten per cent from its 1986 research budget, hitting research harder than any other field of government spending. After five heady years of strong support for science in France, laboratory staff and university lecturers are shocked, and were issuing posters last week claiming that French research was "in a coma".

One of the latest and most extraordinary blows, however, is not of the government's making. The Conseil d'État, effectively the French supreme court, has ruled that a body which for three years had made all the appointments and promotions in France's premier research council. the Centre National de la Recherche Scientifique (CNRS), was illegally elected.

This extraordinary decision, made on the basis of a legal technicality, to disestablish and annul the "Comité National" of CNRS, in theory invalidates all decisions taken by that body since 1983 , thus affecting many of the academic scientists and technicians in France. union power. government.
In practice, the decision may play into the government's hands, as its science advisers have long felt that the Comité National is too dominated by trades union interests. Paradoxically, it was a union that first made the legal complaint to the Conseil d'État back in 1983, over an election which had been designed to reduce

Now, the ministry of research and the council of ministers will have the freedom to define a completely new election procedure at just the moment they would have desired - after a change of government from the political left to the right.

Appointments and promotions made by the Comité National since 1983 are thought likely to stand. But young researchers who recently attended interview boards arranged by the Comité and have been offered places in CNRS are less lucky. Some 375 of the 500 affected will be offered one-year temporary posts instead - to be reviewed next year when a new Comité is in place - and the others will fall by the wayside. This represents a 25 per cent reduction in the scientific recruitment rate projected by the previous

Robert Walgate

Italian biotechnology

\section{New initiative is called for}

\section{Rome}

I I A Y needs to spend a million million lire ( $\{420$ million) on a massive biotechnology programme over the next five years, according $t(0)$ a new report from the Italian National Committee for Biotechnologies. That, says Minister of Research Luigi Granclli, will give the government a tool to make Italy competitive in previously neglected sectors such as chemicals and agriculture.

Four areas are earmarked for funds: fundamental research in public centres and universitics including three special projects from the Consiglio Nazionale della Ricerca (CNR), the national research council (25 per cent of funds). national research involving both scientific bodics and industry (40 per cent), the finance of research societies and stimulation of industrial activity $(25$ per cent $)$ and training of researchers (10 per cent).

Established in July 1985 by Granelli. the committec includes 14 representatives from universities and public research centres and eight from industry. Coordinated by Professor Arturo Falaschi, director of the CNR Institute of Genetic Enginecring in Pavia, the report looks largely at the short term. In countries such as the United States and Japan. says the report, basic research in biotechnology is strongly supported by government, with private investment strong in biomedicine in the United States and in agriculture in Japan. In Europe, adds the report, the United Kingdom leads in biotechnology, but good state-financed programmes have been launched elsewhere.

Italy has good scientists, says Professor Luigi Rossi Bernardi, CNR president, as well as a good research tradition at the Institute of Molecular Biology. And there is the new International Centre for Genetic Engineering and Biotechnology in Trieste (see p.3). But this is not enough for Italy to catch up with other nations.

The biomedical field, says the report, is likely to yield returns in the short term, while agriculture, the food industry and fine chemicals have good medium-term prospects. So the report suggests doubling in five years the number of researchers in biotechnology in public centres such as CNR and ENEA (the national centre for alternative energy), as well as in the universities and health ministry, rather than in industry.

To coordinate the programme, it is suggested that either the present committee should be institutionalized or a National Institute of Biotechnology should be set up like that for nuclear physics
US space

\section{Air Force moves on launchers \\ Washington}

THE US Air Force has announced plans to build at least twelve medium launch vehicles (MLVs) as an alternative to the space shuttle for launching military payloads. In seeking the new rocket, the Air Force has indicated it wants potential suppliers to develop a commercial version of the rocket to compete with Europe's Ariane for commercial payloads.

The new rocket will be able to launch 10,000 -lb payloads into low Earth orbit, and $2.200-\mathrm{lb}$ payloads into a 10.000 -mile high circular orbit. The Air Force intends to use the new rocket primarily to launch its Navstar satellites, part of a new Global Positioning System under development.

Air Force interest in a complementary commercial vehicle may seem odd, but building a launch vehicle with commercial applications would have the obvious benefit of spreading development costs. Air Force Secretary Edward C. Aldridge has consistently shown concern for the viability of the US space programme, according to space policy consultant Christopher Roberts, and by providing a steady customer, the Air Force can go a long way towards assuring the success of a commercial launcher. John Pike of the Federation of American Scientists takes a more cynical view, believing that the new MLV results from an "unholy alliance" between the Air Force and the rocket manufacturers. As Pike sees it, the Air Force gains more positions for uniformed officers in its space command, and the manufacturers get to crank up their production lines.

Money for starting the procurement process of the new MLVs was in the urgent supplement appropriations bill passed by Congress last week. Also in the appropriations bill were funds for an additional 13 Titan 34D7 rockets, the workhorse of the Titan series. With the new orders, Martin Marietta, the manufacturer of the Titan 34D7, will be in a position to compete with Ariane-4, due to launch next year, should the company decide to enter the commercial launch arena.

In a related development, the National Aeronautics and Space Administration (NASA) announced last week that it was offering Indonesia the opportunity to launch its Palapa communications satellite aboard a Delta rocket. The Palapa satellite had been scheduled to fly on the shuttle last month. If Indonesia accepts. NASA will have to build one more Delta to meet its launch commitments. But NASA denies that the new Delta would mark NASA return to expendable launch vehicles.

Joseph Palca 